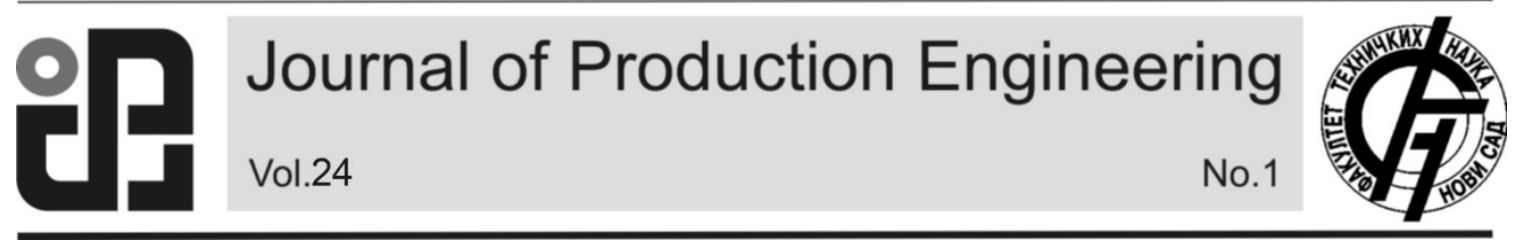

JPE (2021) Vol.24 (1)

Tomov, M., Abazovski, L., Ignatovska, A.

\title{
CONTRIBUTION TO THE SPC IMPLEMENTATION BY SELECTING AN APPROPRIATE VARIABLE CONTROL CHART
}

\author{
Received: 04 March 2021 / Accepted: 10 June 2021
}

\begin{abstract}
The research in this paper contributes to the practical implementation of the Statistical Process Control $(S P C)$, primarily in the serial production by selecting an appropriate variable control chart. The paper proposes a procedure algorithm where the deciding criteria used to select the variable control chart include: the data distribution type (whether an approximately normal distribution or not), the number of elements in the subgroup ( $n$ ) for grouped data, the shift size value and the percentage difference between the shift size value and the mean value of the shifts calculated for each subgroup. The paper explains the proposed algorithm using examples with appropriately drawn control charts, which algorithm essentially represents an extension of the algorithm presented in ISO 7870-2:2013.
\end{abstract}

Key words: control chart, normal distribution, statistical process control, shift size.

Doprinos implementaciji SPC kroz odgovarajući izbor variabilne kontrolne karte. Istraživanje u ovom radu doprinosi praktičnoj primeni Statističke kontrole procesa (SPC), pre svega u serijskoj proizvodnji, u delu odabira odgovarajuće variabilne kontrolne karte. U radu se predlaže algoritam za delovanje u kome su presudni kriterijumi $u$ odnosu na koje se vrši izbor variabilne kontrolne karte: vrsta distribucije podataka (približno normalna distribucija ili ne), broj elemenata u podgrupi (n) u grupisanim podacima vrednost veličine smene $i$ procentualna razlika između vrednosti ,veličine smene” i srednje ,, veličine smene” izračunatih za svaku podgrupu. Korišćenjem primera, za koje se crtaju odgovarajuće kontrolne karte, objašnjava se predloženi algoritam, koji je u suštini produžetak algoritma predstavljenog u ISO 7870-2: 2013.

Ključne reči: kontrolna karta, normalna distribucija, statističke kontrole procesa, veličina smene.

\section{INTRODUCTION}

Companies increasingly rely on statistical quality control methods for quality management and view them as a competitive advantage [1]. Statistical process control - SPC, represents a part of the statistical quality control and relates to the control during the execution of the production process or the services.

The SPC methodology is applied in different ways, but generally relies on the following two main activities: established the statistical status of the process and undertaking appropriate measures depending on the established statistical status of the process.

The statistical status of the process is established using control charts. In essence, control charts, as basic tools of SPC, help determine whether the process contains variations attributable to accompanying causes or the process only contains inherent causes.

Since control charts have a high practical application and significance, today we can encounter a lot of surveys that refer to their specificity, efficiency and effectiveness of application within the framework of multiple methods and principles $[2,3,4,5,6]$.

In literature we encounter a lot of different types of control charts. A lot of them are standardized and their characteristics, advantages, limitations, the calculation methods of their control limits and interpretation are explained in the standards: ISO 7870-2 (Shewhart control charts) [7], ISO 7870-3 (Acceptance control charts) [8], ISO 7870-4 (Cumulative sum charts) [9] and
ISO 7870-5 (Specialized control charts) [10].

The application of several different types of control charts for the same process, can bring into question the decision on the statistical status of the considered process, if the applied control charts yield conflicting results. This situation leads to the need for detailed and in-depth knowledge of the characteristics of each control chart.

In practice, especially with respect to serial production processes typically encountered in the automobile industry, the people mostly use $\overline{\mathrm{x}}$ and $\mathrm{R}$ control charts, followed by $\mathrm{X}$ and s control charts. The chart type selection in these circumstances usually arises from the experience of the operators, the client requirements, or the possibilities of the available software used to prepare them.

The available literature contains little information regarding the control chart selection method, i.e., which control chart for which process would yield more relevant information about its variability. Thus, [7, 10, 11] provide algorithms and recommendations for the selection of variables and attributes control charts.

According to ISO 7870-2:2013 [7], the main deciding factor for the selection of a variable control chart is the size of the group, i.e. the subgroup (n). In [11], in addition of the size of the subgroup (n), another deciding factor for the selection of the control chart is also the "shift size" characteristic.

However, the recommendations of both $[7,11]$ do not include the specialized control charts. The authors 
of this paper believe this to be a serious flaw, because ISO 7870-5: 2014 [10] itself, which refers to specialized control charts states that Shewhart control charts, in certain cases may be inadequate, insufficient, or less efficient in detecting the unnatural patterns of variation of the process.

Another deficiency that can be attributed to the recommendations in $[7,11]$ is that they start from the assumption that the data for which the control charts are draws comply with the law of normal distribution.

This gave rise to the idea to implement the research in this paper, which will attempt to suggest a variable control chart selection method as an extension of the recommendations in $[7,10,11]$, which will provide a contribution to the SPC practice, especially with respect to the establishment of the statistical status of the process.

\section{ACTIVITIES FOR THE PRACTICAL IMPLEMENTATION OF SPC}

Figure 1 shows the activities for the practical implementation of SPC. Every intent to implement SPC must begin by a decision of top management, because SPC implementation is a long process which requires additional human and financial resources. After the decision to implement SPC has been made, then the process and the quality characteristic subject to the statistical control should be selected. The third step of the algorithm presented in Figure 1 is essential for the proper implementation of the SPC methodology. We have already mentioned, the tool used to establish the statistical status of the process are the control charts. The existence of many types of control charts makes the decision in this step difficult. The research in this paper should help and provide contribution to this phase of the practical SPC implementation. After applying the selected control chart, the chart is read and interpreted.

The control chart shows whether the process is under statistical control or not. If the process is under statistical control, then the process capability is calculated, i.e., the indices $c_{p}$ and $c_{p k}$. If the process is statistically stable and capable then it is also predictable and, as such, represents the basic prerequisite for the satisfaction of its users.

If the process is not under statistical control or if it is not capable, then this requires a decision to eliminate the causes. Usually, this requires a team to find the causes and eliminate them or reduce their impact. To find and eliminate the causes, the team usually implements specific problems solving methods or tools.

\section{VARIABLE CONTROL CHART SELECTION ALGORITHM}

To overcome the deficiencies in the control charts selection recommendations, mentioned in the introduction, the authors of this research propose a variable control chart selection methodology, shown on the algorithm in Figure 2. The fundamental supposition for the variable control chart selection algorithm is that "the characteristics of the applied control chart should not influence the decision about the actual statistical status of the process, i.e., the applied control chart should represent the actual statistical status of the process".
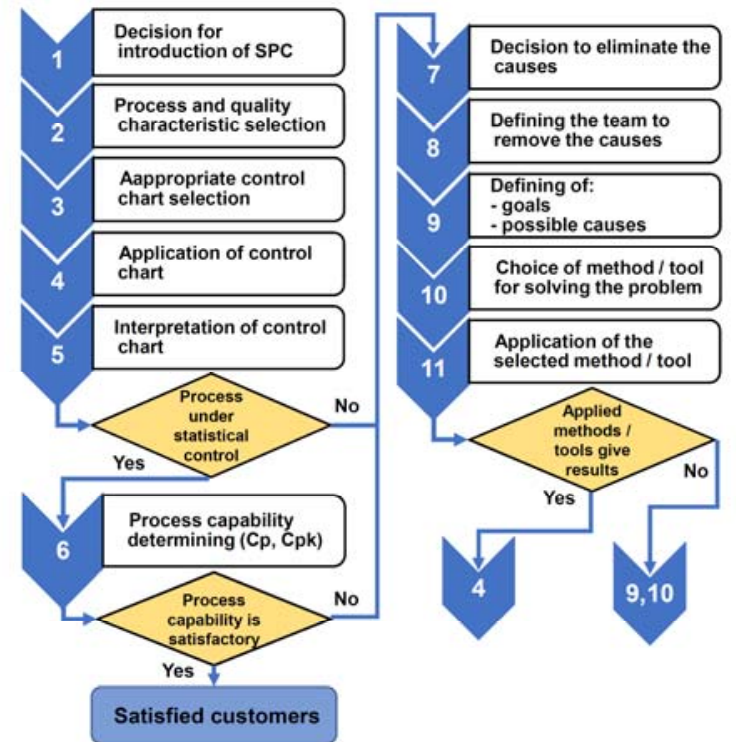

Fig. 1. Activities for implementation of SPC

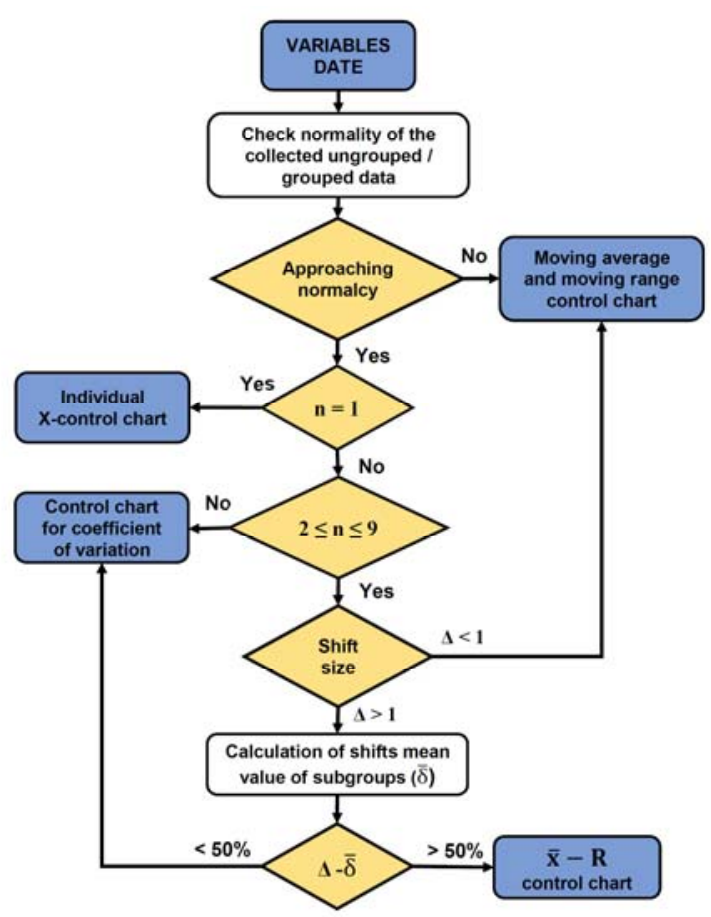

Fig. 2. Variable control chart selection algorithm

The first step of the algorithm, Figure 2, verifies the data distribution type, i.e., whether the data approximately follow the normal distribution law. The data can be added (registered) in an ungrouped form or, for specific purposes, in an already grouped form. If the data are grouped, then the distribution can also be verified using the mean value for the groups, i.e., by determining the group mean value distribution. This research adopted that the data distribution normalcy is determined by a calculation method using the coefficients $\alpha_{3}$ (asymmetry coefficient) and $\alpha_{4}$ (kurtosis).

The asymmetry coefficient is calculated in accordance with the central moment of the third order, 
as follows:

$$
\alpha_{3}=\frac{\mu_{3}}{\sigma^{3}}=\frac{\mu_{3}}{\sqrt{\mu_{2}{ }^{3}}}
$$

where $\mu_{r}$ is the central moment of r-order and is calculated as follows:

$$
\mu_{r}=\frac{1}{n} \sum_{i=1}^{n}\left(x_{i}-\bar{x}\right)^{r}
$$

while $\mathrm{n}$ is the total number of considered data, i.e.:

$$
\begin{gathered}
\mu_{2}=\frac{1}{n} \sum_{i=1}^{n}\left(x_{i}-\bar{x}\right)^{2}=\sigma^{2} \\
\mu_{3}=\frac{1}{n} \sum_{i=1}^{n}\left(x_{i}-\bar{x}\right)^{3}
\end{gathered}
$$

The kurtosis $\alpha_{4}$ is calculated in accordance with the central moment of the fourth order, as follows:

$$
\alpha_{4}=\frac{\mu_{4}}{\sigma^{4}}=\frac{\mu_{4}}{\mu_{2}{ }^{2}}
$$

where $\mu_{4}$ is calculated as follows:

$$
\mu_{4}=\frac{1}{n} \sum_{i=1}^{n}\left(x_{i}-\bar{x}\right)^{4}
$$

It is known that in real production it is very difficult for the data to strictly follows the normal distribution law. Therefore, this research accepts the terminology approximately normal distribution. The distribution is considered approximately normal if the coefficients $\alpha_{3}$ and $\alpha_{4}$ are in the following range: $-0.5 \leq \alpha_{3} \leq+0.5$ and $+2.5 \leq \alpha_{4} \leq+3.5$.

According to the algorithm in Figure 2, if, after the calculation of the values of the coefficients $\alpha_{3}$ and $\alpha_{4}$, it turns out that the data do not approximately follow the normal distribution law, then the one should use the moving average and moving range control charts. This recommendation derives from the fact that for the moving average control chart the individual impact of each data entry relative to the group is much more emphasized than for the $\overline{\mathrm{x}}$ control chart.

In order to prove specific claims, this research uses theoretical data about processes to illustrate specific situations.

Thus, Figure 3 a) shows the moving average control chart made with data from Table 1, which do not follow the normal distribution law, i.e., for ungrouped data $\alpha_{3}=$ $-0.1, \alpha_{4}=+1.9$, or, for grouped data $\alpha_{3}=+0.1, \alpha_{4}=+2.0$. On the other hand, Figure $3 \mathrm{~b}$ ) shows the $\overline{\mathrm{x}}$ control chart for the same data. The size of the subgroup for both control chart is 5 data entries. Figure 3 clearly shows that moving average control chart exhibits more deficiencies regarding the statistical statis than the $\bar{x}$ control chart.

According to the algorithm on Figure 2, if the data approximately follow the law of normal distribution, then one should decide how to group the data and how large to make the size of the group (subgroup) n. However, we need to mention here that, when grouping the data into subgroups, the data within a subgroup should be obtained sequentially, but also under the same conditions or unchanged process input conditions. If data are not grouped, i.e., if the size of the subgroup is one $(n=1)$, then one should clearly select a individuals (X) control chart, because this is the only control chart used when there is no grouping of data and serves to verify the statistical status of the process based on the collected individuals data.

If the data are grouped, the number of data (n) in a subgroup is also significant, i.e., whether it is in the range " $2 \leq n \leq 9$ " or " $n \geq 10$ ".

\begin{tabular}{|c|c|c|c|c|c|}
\hline \multirow{2}{*}{$\begin{array}{c}\text { Number of } \\
\text { subgroup (n) }\end{array}$} & \multicolumn{5}{|c|}{ Value of the concerned process } \\
\cline { 2 - 6 } characteristics \\
\hline 1 & 1 & 2 & 3 & 4 & 5 \\
\hline 2 & 30.583 & 30.585 & 30.58 & 30.587 & 30.59 \\
\hline 3 & 30.588 & 30.586 & 30.579 & 30.573 & 30.576 \\
\hline 4 & 30.586 & 30.575 & 30.572 & 30.57 & 30.578 \\
\hline 5 & 30.566 & 30.571 & 30.574 & 30.566 & 30.573 \\
\hline 6 & 30.58 & 30.584 & 30.574 & 30.568 & 30.587 \\
\hline 7 & 30.582 & 30.589 & 30.59 & 30.574 & 30.567 \\
\hline 8 & 30.578 & 30.572 & 30.569 & 30.582 & 30.586 \\
\hline 9 & 30.586 & 30.579 & 30.587 & 30.583 & 30.588 \\
\hline 10 & 30.581 & 30.566 & 30.575 & 30.573 & 30.57 \\
\hline 11 & 30.568 & 30.575 & 30.57 & 30.567 & 30.572 \\
\hline 12 & 30.579 & 30.583 & 30.586 & 30.589 & 30.591 \\
\hline 13 & 30.58 & 30.585 & 30.588 & 30.574 & 30.579 \\
\hline 14 & 30.587 & 30.573 & 30.574 & 30.571 & 30.577 \\
\hline 15 & 30.582 & 30.586 & 30.584 & 30.575 & 30.583 \\
\hline 16 & 30.58 & 30.591 & 30.565 & 30.578 & 30.579 \\
\hline 17 & 30.577 & 30.583 & 30.587 & 30.581 & 30.57 \\
\hline 18 & 30.591 & 30.589 & 30.587 & 30.588 & 30.581 \\
\hline 19 & 30.565 & 30.569 & 30.565 & 30.579 & 30.588 \\
\hline 20 & 30.576 & 30.584 & 30.575 & 30.578 & 30.569 \\
\hline 1 & Exyyyyy & & &
\end{tabular}

Table 1. Example (case 1) of values of the concerned process characteristics
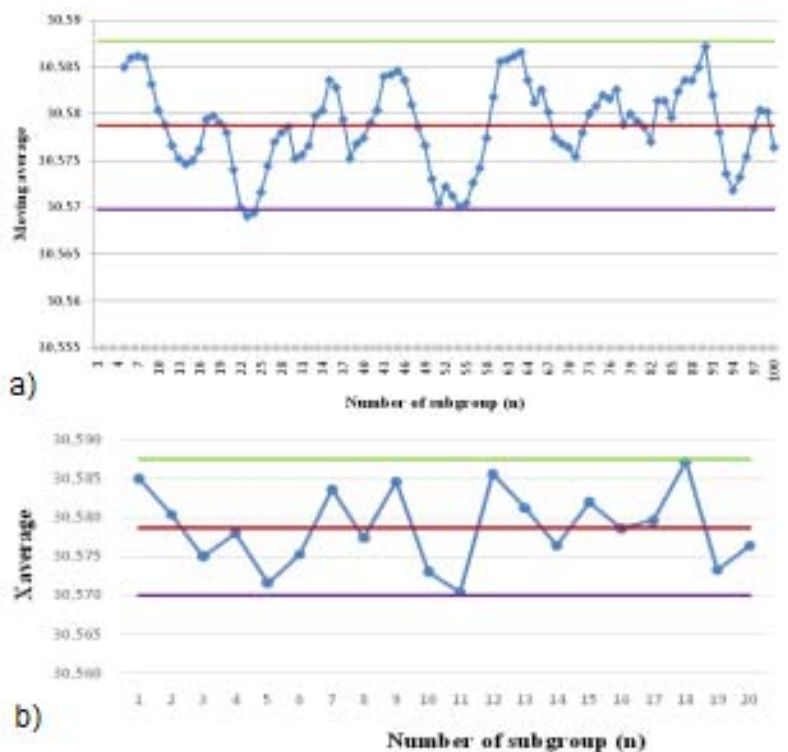

Fig. 3. a) Moving average control chart and b) $\bar{x}$ (average) control chart

If $\mathrm{n} \geq 10$, then [7] recommends the combination $\overline{\mathrm{x}}-$ $s$ control charts. The research in this paper showed that instead of drawing two control charts $\overline{\mathrm{x}}$ and $\mathrm{s}$, it suffices to implement and draw a control chart for coefficient of variation. The control chat for coefficient of variation is simply a "copy" of the s-chart. When the data approximately follow the normal distribution, in this research the authors did not manage to prove a process status where the $\mathrm{s}-$ chart shows a process in statistical control and the $\bar{x}$ - chart shows a process out of statistical control, which justifies the previously mentioned recommendation to use a control chart for coefficient of variation as part of the group of specialized control charts.

When the size of the group (subgroup) is $2 \leq \mathrm{n} \leq 9$, 
then it is necessary to calculate the shift size $(\Delta)$. The shift size acquires the largest value of the shift $(\delta)$ calculated for all subgroups. The shift $(\delta)$ for each subgroup is calculates as follows [11]:

$$
\delta=\frac{\left|\mu_{1}-\mu_{0}\right|}{s}
$$

where:

$\delta$ - shift of the subgroup,

$\mu_{1}-$ mean value of the subgroup,

$\mu_{0}$ - mean value of all subgroup mean values, $\mathrm{s}$ - standard deviation of the units.

According to [12], the shift size $(\Delta)$ is considered "small" if its value is less than one, i.e., if its value is greater than one then the shift size $(\Delta)$ is considered as "large".

If $\Delta$ is small, then the process variations are small and therefore it is recommended to use the moving average and moving range control charts for such a process.

According to the algorithm, if the process has a large $\Delta$ then it is recommended to calculate the mean value of the shifts of the subgroups $(\bar{\delta})$ and compare it to the shift size $(\Delta)$. The difference between $\Delta$ and $\bar{\delta}$ is expressed in percent. If $\Delta-\bar{\delta}$ is less than $50 \%$, it is recommended to use a control chart for coefficient of variation. Table 2 contains data for which control chart for coefficient of variation, $\overline{\mathrm{x}}-$ chart and $\mathrm{R}$ - chart have been calculated and drawn. The data in Table 2 approximately follow the law of normal distribution, i.e., for them $\alpha_{3}=-0.2, \alpha_{4}=+2.8, \Delta$ is 1.5 , while $\Delta-\bar{\delta}=$ $46 \%$. In such an example the control chart for coefficient of variation, Figure 4 a), shows a process out of statistical control because there are points outside of the control limits, but also there is a RUN. On the other hand, the $\overline{\mathrm{x}}$ control chart, Figure $4 \mathrm{~b}$ ), and $\mathrm{R}$ control chart, Figure $4 \mathrm{c}$ ), show a process in statistical control.

\begin{tabular}{|c|c|c|c|c|c|}
\hline \multirow{2}{*}{$\begin{array}{c}\text { Number of } \\
\text { subgroup (n) }\end{array}$} & \multicolumn{5}{|c|}{$\begin{array}{c}\text { Value of the concerned process } \\
\text { characteristics }\end{array}$} \\
\cline { 2 - 6 } & 1 & 2 & 3 & 4 & 5 \\
\hline 1 & 30.583 & 30.578 & 30.585 & 30.587 & 30.59 \\
\hline 2 & 30.575 & 30.575 & 30.579 & 30.581 & 30.576 \\
\hline 3 & 30.586 & 30.582 & 30.581 & 30.591 & 30.578 \\
\hline 4 & 30.587 & 30.584 & 30.582 & 30.579 & 30.58 \\
\hline 5 & 30.569 & 30.571 & 30.583 & 30.579 & 30.584 \\
\hline 6 & 30.58 & 30.581 & 30.582 & 30.581 & 30.58 \\
\hline 7 & 30.583 & 30.575 & 30.577 & 30.58 & 30.583 \\
\hline 8 & 30.578 & 30.575 & 30.576 & 30.582 & 30.575 \\
\hline 9 & 30.584 & 30.582 & 30.588 & 30.59 & 30.582 \\
\hline 10 & 30.581 & 30.578 & 30.58 & 30.575 & 30.573 \\
\hline 11 & 30.58 & 30.584 & 30.578 & 30.575 & 30.571 \\
\hline 12 & 30.581 & 30.584 & 30.575 & 30.588 & 30.586 \\
\hline 13 & 30.584 & 30.585 & 30.588 & 30.584 & 30.579 \\
\hline 14 & 30.583 & 30.58 & 30.575 & 30.579 & 30.577 \\
\hline 15 & 30.585 & 30.586 & 30.587 & 30.58 & 30.589 \\
\hline 16 & 30.573 & 30.58 & 30.579 & 30.578 & 30.579 \\
\hline 17 & 30.582 & 30.584 & 30.587 & 30.581 & 30.578 \\
\hline 18 & 30.59 & 30.587 & 30.583 & 30.585 & 30.583 \\
\hline 19 & 30.58 & 30.579 & 30.583 & 30.582 & 30.585 \\
\hline 20 & 30.59 & 30.585 & 30.581 & 30.584 & 30.583 \\
\hline
\end{tabular}

Table 2. Example (case 2) of values of the concerned process characteristics

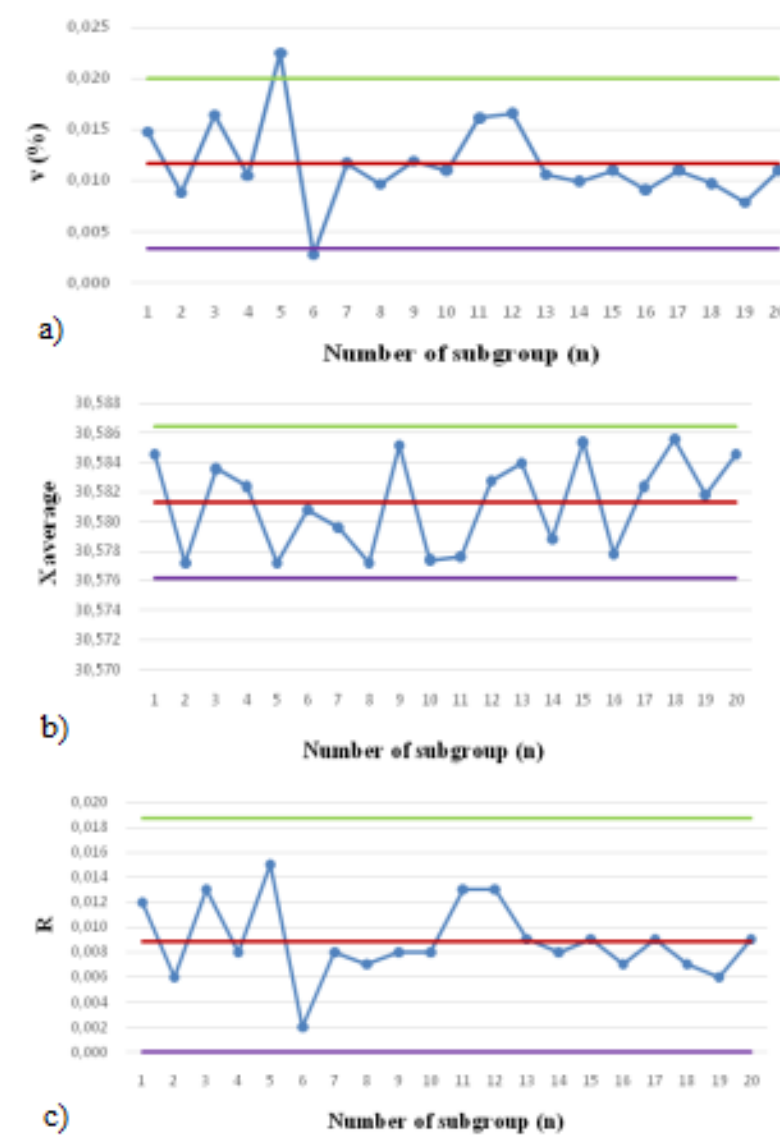

Fig. 4. a) Control chart for coefficient of variation b) $\bar{x}$ (average) control chart c) R control chart

\begin{tabular}{|c|c|c|c|c|c|}
\hline \multirow{2}{*}{$\begin{array}{c}\text { Number of } \\
\text { subgroup (n) }\end{array}$} & \multicolumn{5}{|c|}{ Value of the concerned process } \\
\cline { 2 - 5 } & 1 & 2 & 3 & 4 & 5 \\
\hline 1 & 30.583 & 30.578 & 30.575 & 30.587 & 30.58 \\
\hline 2 & 30.57 & 30.567 & 30.58 & 30.571 & 30.576 \\
\hline 3 & 30.58 & 30.582 & 30.581 & 30.583 & 30.578 \\
\hline 4 & 30.587 & 30.584 & 30.582 & 30.579 & 30.573 \\
\hline 5 & 30.569 & 30.571 & 30.583 & 30.579 & 30.584 \\
\hline 6 & 30.585 & 30.583 & 30.582 & 30.581 & 30.58 \\
\hline 7 & 30.583 & 30.589 & 30.577 & 30.574 & 30.583 \\
\hline 8 & 30.578 & 30.571 & 30.57 & 30.582 & 30.584 \\
\hline 9 & 30.585 & 30.589 & 30.59 & 30.591 & 30.58 \\
\hline 10 & 30.566 & 30.579 & 30.569 & 30.576 & 30.573 \\
\hline 11 & 30.579 & 30.575 & 30.57 & 30.565 & 30.571 \\
\hline 12 & 30.581 & 30.584 & 30.579 & 30.588 & 30.586 \\
\hline 13 & 30.574 & 30.585 & 30.588 & 30.584 & 30.579 \\
\hline 14 & 30.583 & 30.584 & 30.58 & 30.579 & 30.577 \\
\hline 15 & 30.579 & 30.586 & 30.587 & 30.58 & 30.59 \\
\hline 16 & 30.583 & 30.58 & 30.585 & 30.578 & 30.579 \\
\hline 17 & 30.582 & 30.584 & 30.587 & 30.581 & 30.575 \\
\hline 18 & 30.591 & 30.578 & 30.574 & 30.585 & 30.582 \\
\hline 19 & 30.58 & 30.581 & 30.586 & 30.582 & 30.579 \\
\hline 20 & 30.577 & 30.585 & 30.581 & 30.578 & 30.583 \\
\hline
\end{tabular}

Table 3. Example (case 3) of values of the concerned process characteristics

If $\Delta-\bar{\delta}$ is greater than $50 \%$, the algorithm recommends the use of $\bar{x}-R$ control charts. Table 3 contains data for which $\bar{x}$ control chart, $\mathrm{R}$ control chart and control chart for coefficient of variation have been calculated and 
drawn. The data in Table 3 approximately follow the law on normal distribution, i.e., for them $\alpha_{3}=-0.5, \alpha_{4}=$ $+3.0, \Delta$ is 1.5 , while $\Delta-\bar{\delta}=58 \%$. In such an example the $\bar{x}$ control chart, Figure 5 a), shows a process out of statistical control because there are points outside of the control limits, but also there is a RUN. On the other hand, the control chart for coefficient of variation show a process in statistical control.

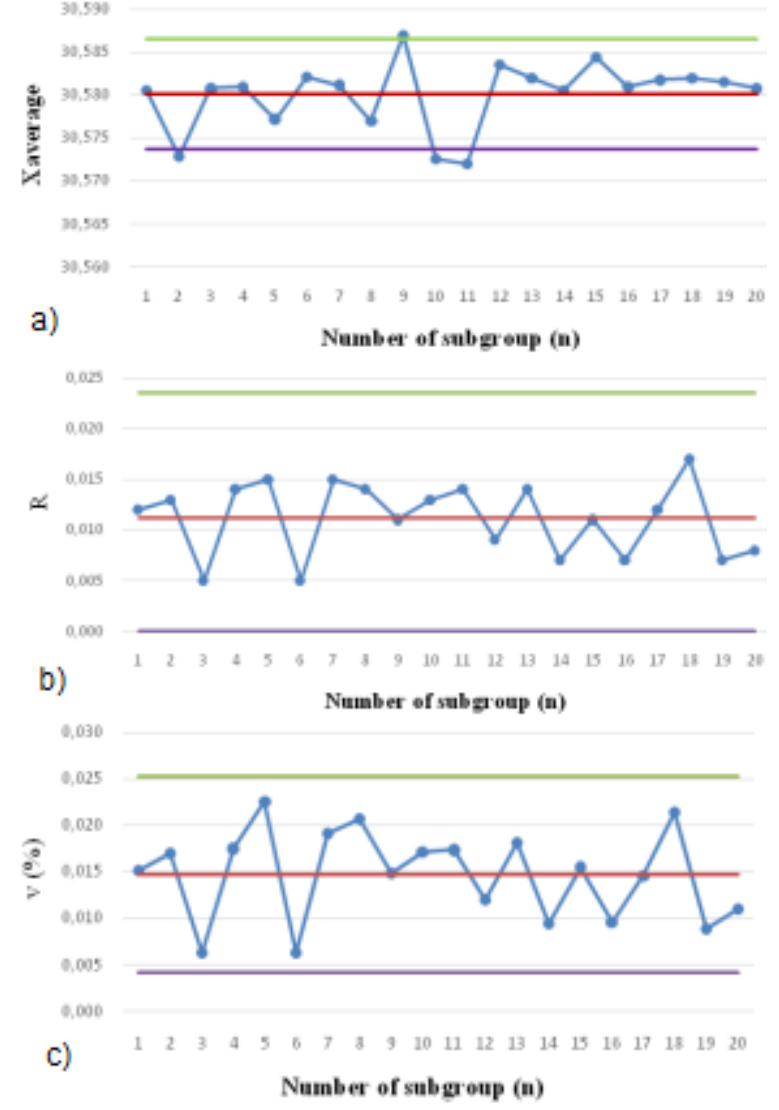

Fig. 5. a) $\bar{x}$ (average) control chart b) R control chart c) Control chart for coefficient of variation

\section{CONCLUSION}

The research in this paper bring us to the following conclusions:

- The selection of an appropriate variable control chart type has been shown to be essential for the making of a correct decision regarding the statistical status of a process.

- The proposed algorithm represents a good basis for further scientific research, but it also has a significant applicative value. Following the activities of the algorithm will enable users to make consistent decisions when selecting a appropriate type of variable control chart.

- The introduction of the variable shift size $(\Delta)$, which is a kind of measure of the variability of the concerned data, has proven a successful criterion for overcoming certain deficiencies common when using $\overline{\mathrm{x}}-\mathrm{R}$ control charts.

\section{REFERENCES}

[1] Tarí J. J., Molina J. F., Castejón J. L.: The relationship between quality management practices and their effects on quality outcomes, European Journal of Operational Research, vol. 183, no. 2, pp. 483-501,2007. https://doi.org/10.1016/j.ejor.2006.10.016.

[2] Godina R., Matias J., Azevedo G. S.: Quality improvement with statistical process control in the automotive industry, International Journal of Industrial Engineering and Management (IJIEM), vol. 7 no 1, pp. 1-8, 2016.

[3] Burlikowska M. D.: Quality estimation of process with usage control charts type $X-R$ and quality capability of process $C p$, $C p k$, Journal of Materials Processing Technology, vol. 162-163, pp. 736743, 2005. https://doi.org/10.1016/j.jmatprotec.2005.02.210.

[4] Jirasettapong P., Rojanarowan N.: A guideline to select control charts for multiple stream processes control, Engineering Journal, vol. 15, no. 3, 2011. https://doi.org/10.4186/ej.2011.15.3.1.

[5] Zhang J., Li Z., Wang Z.: Control chart for monitoring the coefficient of variation with an exponentially weighted moving average procedure, Quality and Reliability Engineering International, vol. 34, no. 2, pp. 188-202, 2018. https://doi.org/10.1002/qre.2247.

[6] Adeoti O.A., Olaomi J.O.: Process capability index - based control chart for variables, South African Journal of Industrial Engineering, vol 28(2), pp 28-36, 2017, https://doi.org/10.7166/282-1353.

[7] ISO 7870-2:2013. Control charts - Part 2: Shewhart control charts. First edition, 2013.

[8] ISO 7870-3:2012. Control charts - Part 3: Acceptance control charts. First edition, 2012.

[9] ISO 7870-4:2011. Control charts - Part 2: Cumulative sum charts. First edition, 2011.

[10] ISO 7870-5:2014. Control charts - Part 5: Specialized control charts. First edition, 2014.

[11] Montgomery C.D.: Introduction to statistical quality control, Sixth edition. New York, NY, USA: John Wiley \& Sons, 2009.

[12] Al-Sultan S. K., Rahim M. A.: Optimization in quality control, First edition. New York, NY, USA:Springer-Science+Business Media, 1997.

ACKNOWLEDGMENT: The authors would like to acknowledge Prof. Mikolaj Kuzinovski (in memoriam) whose research in the field of SPC had a huge impact on the development of SPC methodology at the Institute of Production Engineering and Management, Faculty of Mechanical Engineering, „Ss. Cyril and Methodius” University in Skopje, North Macedonia.

Authors: Associate prof. Mite Tomov Ph.D, Anastasija Ignjatovska grad. mech. eng., "Ss. Cyril and Methodius" University in Skopje, Faculty of Mechanical Engineering-Skopje, Karpos, 1000 Skopje, North Macedonia, Leonard Abazovski M.Sc., Euroedil-Holding, Skopje, North Macedonia.

E-mail: mite.tomov@mf.edu.mk aneignjatovska@yahoo.com leo.abaz@gmail.com 